\title{
Power and Institutions in Global Standardization * \\ The Role and the Importance of Ambiguity in Institutionalizing New Standards of OSR
}

\author{
LUC BRES AND EMMANUEL RAUFFLET ${ }^{* *}$
}

Macht und Institutionen in globalen Standardisierungsprozessen: Die Rolle und Bedeutung von Ambiguität für die Institutionalisierung neuer Standards für organisatorische Verantwortung

"It [power] is at its most effective when least accessible to observation."

(Lukes 2005: 64)

This paper seeks to understand the success of the International Organization for Standardization (ISO) in creating a platform for the development of ISO 26000, a standard of organizational social responsibility (OSR). The contribution of this paper is twofold. First, neo-institutional theory combined with political theory will help us to understand how ISO successfully managed to attract and maintain the participation of several opposing groups in the development process of its ISO 26000 standard. Second, we introduce here the concept of platform and examine how institutional platforms facilitate the construction of new institutions at an international level. This will lead us to propose an account of how new political places work in the emerging global infrastructure on OSR.

Keywords: ISO 26000, Power and Institutions, Meta-Organization, Governance, Globalization

\section{Introduction}

Our Motivation for this paper stems from a simple, though puzzling, question from field research on the ISO 26000: how to explain the success of the International Organization for Standardization (ISO) in the development of a standard for Organizational Social Responsibility (OSR)? It does so by combining neo-institutional theories and the typology of political places by Bryson and Crosby (Bryson/Crosby 1992) to develop theoretical lenses for investigating ISO's positioning as a platform for the development of this standard. Results presented here are derived from a field-study conducted from 2008 to 2010. They reveal the importance of maintaining a certain degree of ambiguity when developing norms and standards. The importance of ambi-

Submitted on 15.10.2010, revised article accepted on 10.4.2011 after double blind review.

** Msc. and Ph.D. Candidate Luc Bres, HEC Montréal, 5352 avenue du Parc, H2V 4G8 phone: +1 514-495-2694, fax: +1 514-340-5635, e-mail: luc.bres@gmail.com, fields of expertise: Sustainable and Environmental Management, Corporate Social Responsibility, Norms and Standards, Organizational Change.

Prof. Emmanuel Raufflet Ph.D., HEC Montréal, 3000, chemin de la Côte-Sainte-Catherine, H3T 2A7 phone: +1 514-340-6196, fax: +1 514-340-5635, e-mail: emmanuel.raufflet@hec.ca, fields of expertise: Management, Organization and Natural Environment, Social Dimensions in Natural Resource Management. 
guity has already been mentioned by several authors (Douglas 1986; Turcotte/ Pasquero 2001); here we further explore the nature of this ambiguity.

In many ways, the success of ISO in creating a platform for the negotiation of ISO 26000 is amazing. There is indeed strong competition in the development of norms and standards for OSR. Several authors have reported a burst of norms and standards related to OSR over the past few years (ISO Advisory Group on Social Responsibility 2004; Tamm Hallström 2004; Waddock 2008). So much so that in 2005, Lingteringer and Zadek identified more than 300 OSR tools (Ligteringer/Zadek 2005). This proliferation, as Waddock calls it, is problematic because it hampers the emergence of an international institutional infrastructure for organizational social responsibility (Waddock 2008). Yet, standards are only the tip of the iceberg; beyond the competition over standards there is another intense rivalry between the platforms on which those standards are developed. This is particularly noticeable in the case of ISO: habitually enjoying an oligopolistic position as one of the few developers of technical standards applied in engineering and manufacturing, ISO now faces major competitors as with ISO 26000 it is entering a realm closer to public policy (Ruwet 2009; Tamm Hallström 2005). In this field several international organizations already offer well-established platforms for standard development. For instance, since 1977 the International Labour Organization (ILO) has released three editions of its Tripartite Declaration of Principles concerning Multinational Enterprises and Social Policy; in 2000 the United Nations developed the Global Compact (GC) and in the same year the Global Reporting Initiative (GRI) launched its first sustainability reporting guidelines. These organizations, and others, had been developing standards related to OSR for years before the ISO 26000 development process even started.

However, as of 2010, the situation seems to have turned around. After nearly 10 years of intense negotiations, ISO finally reached an international consensus on OSR crowned by the publication of ISO 26000 on 1 November 2010. Moreover, two signals indicate that ISO 26000 is likely to be a reference in terms of OSR:

- ISO has succeeded in attracting and maintaining most of the major players in OSR in the discussion: all the countries from the G-20 major economies; international organizations such as ILO, the UN Global Compact and the OECD; NGOs like the Fair Labor Association; and so on.

- Several national standard bodies and governments have already started to develop their own certifiable version of the ISO 26000 in Portugal and Brazil or will do so soon in Austria and Denmark.

Accordingly, ISO - an organization confined to the development of technical standards until the 1980s - now appears to be a major platform on which the definition of the OSR is negotiated. How to explain this success? This question regarding the success of the ISO 26000 has been asked by several researchers coming from different theoretical streams (Castka/Balzarova 2008; Ruwet 2009; Tamm Hallström 2005).

The contribution of this paper is twofold. First, neo-institutional theory combined with political theory will help us to understand how ISO successfully managed to attract and maintain the participation of several opposing groups in the development process of its ISO 26000 standard. Second, we introduce here the concept of platform 
and examine how platforms facilitate the construction of new institutions at an international level. This will lead us to propose an account of how new political places work in the emerging global infrastructure on OSR.

The remainder of this paper is divided into three sections. In the first section, we describe the qualitative methodology on which our analysis is based. The second prepares the reader to understand our argument by describing the context in which ISO 26000 is developed, useful results from previous research and the theoretical lenses for our investigation. The third section then proposes to explain how ISO succeeded by maintaining a certain ambiguity that we shall further explain.

\section{Case Study Design}

The ISO 26000 development process implies complexity and social innovation. Indeed the number - more than 400 experts - and diversity of the actors involved in this multi-stakeholder negotiation are unprecedented in a non-governmental negotiation on a social issue. The duration of the process, which has officially reached six years from 2004 to 2010 - although it actually started 4 years prior to the official launch - along with its international dimension, have required new and innovative structures. Accordingly, several authors have described ISO 26000 as a very complex and innovative process (Egyedi/Toffaletti 2008: 3; Igalens 2009: 100). The study of a complex and rather understudied phenomenon like this one requires an exploratory methodological design that will facilitate the collection of rich, emergent, "deep" data, some of which is tacit, deeply-embedded and hard to get at. For such phenomena, the case study methodological approach is particularly useful (Patton 2002: 14; Yin 2009: 6). More precisely, the ISO 26000 development process, because of its innovative nature, constitutes a "revelatory case", defined as contemporary phenomenon newly available for study (Yin 2009: 43).

Data were collected from a range of qualitative sources. The first source is composed of (1) 300 publically available internal documents, available on ISO's website ${ }^{1}$. Closer attention was paid to documents establishing operational and decisional procedures for the process, which represent more than 100 texts. (2) A detailed examination of a yet small but growing literature on ISO, namely the 32 articles which contain "ISO 26000 " either in the title, citation or abstract that appear in the ABI/INFORM database. (3) Around 20 academic papers gathered through contact with actors involved in the development of ISO 26000.

The second source stemmed from semi-directed interviews with 15 experts involved in the ISO 26000 development process who seemed likely to be the most influential based on an analysis of ISO 26000's decision structures. Their importance in the decision making process was cross-checked with researchers from different universities also studying ISO 26000, as well as with the authors' informal relations with the participants and, later on, by a new series of 5 interviews with other participants. These 15 interviews ranging from 27 to 150 minutes each were transcribed, resulting in an interview data set of approximately 75,000 words. 
The third source is a set of data gathered from semi-participative observations conducted foremost during ISO's Québec plenary meeting in May 2009. During that event, 70 hours of observation were conducted in the course of one week and more than 100 pages of notes and internal documents were produced or gathered. Further data were generated in fall 2009 during a participative observation. At this occasion, the author was a member of the Québécois mirror committee that gathered on October, 29th 2009 for preparing commentaries on the ISO 26000's draft international standard (DIS).

Data-analysis was processed first by constructing a narrative to make sense of the data along a longitudinal dimension (Langley 1999; Pettigrew 1990). This helped us better understand the political dynamics at work in the process. The different sources of data allowed a triangulation to validate the narrative, that was eventually confirmed with participants in follow-up interviews (Yin 2009). We then started to code the data. Our coding was influenced both by the data (Glaser 1992), and by our conceptual framework (Miles/Huberman 1994). At this point, the analysis of the actors' purposes in the process as well as the outcomes, in terms of regulation, they perceived as likely to emerge from the negotiations appeared to us as meaningful dimensions for the coding. These dimensions allowed us to map and periodize (Langley 1999) the actors' various interests in taking part in this process, and the type of regulation they expected to emerge from the negotiation process. We used different sources of data as a first way to triangulate our finding; we also conducted 5 additional interviews with different participants 2 years after our first series of interviews. These interviews provided information that strengthen the narrative, the mapping and the periodization but did not introduce major changes.

\section{Understanding ISO's Success: Insights from Previous Research and Theories}

\subsection{Institutional Change, Opponents and Advocates of the ISO 26000 Platform}

One convenient distinction that can be drawn from neo-institutionalist literature on institutional change is between opponents and advocates of institutional change (DiMaggio 1991; Greenwood et al. 2002; Seo/Creed 2002; Tolbert/Zucker 1996). For those theorists, generally, opponents are those favored by the existing institutional order who do not want to jeopardize their privileged position (Garud et al. 2007: 961). On contrary, advocates of institutional change are those in less central positions, from the "institutional fringes", who expect to benefit from an institutional reconfiguration (Czarniawska 2009). In practice, power distribution engendered by institutional arrangements can undermine the possibility for change. On the one hand, actors at the center of institutional arrangements may seek to maintain existing arrangements because they benefit from them. On the other hand, peripheral actors may be wary of political places where they feel powerless next to other institutional actors. In any case, this discourages actors from engaging in collaborative dialog about institutional change.

In her recent Ph.D. thesis, Ruwet provides a particularly interesting analysis of the stakeholders involved in the ISO 26000 development process that echoes this distinc- 
tion. According to her, two kinds of stakeholders were involved: the stakeholders that represent interests and those that represent perspectives. The former are often more organized and participate with clearly defined objectives attempting to advance their own agendas. The latter are far less organized, more innovative, and eager to extend the debate to a broad range of issues. In fact, they join the debate with an intention to engage in in-depth discussions on these issues (Ruwet 2009: 10).

Ruwet's (2009) distinction parallels and enriches that made between opponents and advocates of change by neo-institutionalists. Opponents to change are very similar to the stakeholders defending interests as described by Ruwet. They occupy a central position in the field of OSR international regulation and are wary of the coming change. Advocates of change can be assimilated under Ruwet's concept of stakeholders representing a perspective. They come from the institutional fringes with a real interest in institutional change. Traditionally marginalized from political processes, they too are reluctant to participate because they have often been pushed aside by the more powerful actors in the OSR field.

\section{Illustration:}

In the ISO 26000 development process, labor representatives provide a good example of stakeholders defending interests. For years, they have been engaged in the development of standards in the field of OSR. For instance, they participated in the Tripartite Declaration of Principles concerning Multinational Enterprises and Social Policy within the ILO, in the development of several norms for occupational health and safety, and so on. Their long-standing and strong position in the OSR international regulation field allowed them to play a major role in the overall process. However, since the ILO is engaged in a similar process of norm development, labor representatives participated reluctantly. As expressed in International Trade Union Confederation $n^{\circ} 26$ documents, the ILO officially challenges the legitimacy of a semi-private organization such as ISO to develop an OSR standard. It nonetheless eventually joined in the ISO process.

At the other extreme, one can consider NGOs as good examples of stakeholders defending perspectives. In this process, NGOs represent a wide range of interests which may even conflict at times. Examples of NGOs range from anti-child labor activists to biodiversity champions. They certainly bring different views to the discussion, but also find it a challenge to achieve a common position at ISO, and to maintain it as soon as debates get heated. Meanwhile, some of the world's most famous NGOs, such as Greenpeace, considered it a waste of resources to participate in the process.

In the next section we discuss how potentially conflicting actors are being mobilized to collaborate in the development of the ISO 26000 process.

\subsection{An Ambiguous Field}

In describing multi-stakeholder collaborative negotiation processes, Pasquero and Turcotte have underlined the importance of maintaining some degree of ambiguity 
throughout the negotiation process (Turcotte/Pasquero 2001: 459). We shall now analyze further the nature of this ambiguity.

A first level of ambiguity concerns the field of international OSR. This field is fairly close to what has been described as the field of global environmental regulation by Maguire and Hardy (2006: 8-9):

"Such fields are constituted by sets of institutional entrepreneurs including government bodies, business groups and NGOs, 'who seek to influence a shared outcome (such as regulation) and pay attention to one another' (McNichol/ Bensedrine 2003: 220). They are Arenas of power relations, where institutional entrepreneurs 'compete over the definition of issues and the form of institutions that will guide organizational behaviour' (Hoffman, 1999: 352) such transnational negotiations represent a space 'where interactions take place and behavioural patterns get structured'."

As global governance is still rather undefined, a high level of ambiguity exists across the entire field. More precisely, the nature and definition of the new global political places, namely places where global rules for OSR would be defined, is not clear. Beck recently called for the advent of a new global order regulated by a "quasi-state" (Beck 2008). Waddock has foreseen an emerging new institutional infrastructure on corporate social responsibility that still needs to be further developed (Waddock 2008: 106). For most actors engaged in the field of OSR this incompleteness of the global governance is full of ambiguities, uncertainties and potential conflicts. In terms of institutional change, this has been described by Dorado as a "hazy field" where cognitive, social and material support necessary to institutional change are not easy to access for the actors (Dorado 2005).

In this context, and since the beginning of the 1980s, authors have begun to theorize organizations capable of establishing a link between actors from different institutional fields: Trist, for instance, has developed the concept of "referent organizations" that facilitate interorganizational collaboration (Trist 1983); Brown and David describe "bridging organizations" which link actors both local and global as well as weak and powerful (Brown 1991); and more recently Ahrne and Brunsson have defined "metaorganizations" as organizations with organizations as members instead of individuals (Ahrne/Brunsson 2008). However, these concepts remain under-theorized.

Apart from this general ambiguity within the field of international OSR, ISO itself as an organization occupies an ambiguous position: neither a public nor a private instance of regulation. As a matter of fact, participants in the ISO 26000 development process have been noted to provide contradictory statements when asked whether ISO was a public or private organization (Tamm Hallström 2004: 20). In its official documents, ISO describes itself as a bridge between private and public sectors ${ }^{2}$. Thus it is not clear what type of political place ISO has set up for the development of ISO 26000 .

2 http://www.iso.org/iso/about.htm, website accessed in October 2010. 


\subsection{Three Categories of Political Places by Bryson and Crosby}

While international political places remain to be more fully theorized, national level political places have been the subject of considerable research. Bryson and Crosby connect public action and social structure; they define three types of "shared-power settings" which we here refer to as political places: Courts, Forums and Arenas (Bryson/Crosby 1992: 86). Courts can be discarded here as they deal mainly with the "practice of judging or evaluating" the application of laws and norms (Bryson/Crosby 1992: 108). By contrast, the Forum and Arena concepts are very effective in explaining the ambiguities observed in the ISO 26000 development process. As will be seen in the remainder of this article, the observed ambiguities can be explained by ISO lying at the boundaries separating Forums and Arenas. Most recently, paralleling this distinction, Latour has proposed to redesign traditional national-state bicameralism towards a more explicit Forum/Arena system. His new bicameralism would then be composed of two new assemblies: the upper house akin to a Forum, and the lower house more similar to an Arena. "The distinction between two new assemblies - the first [i.e. the upper house] of which will ask 'How many are we?' and the second [i.e. the lower house] 'Can we live together?' " (Latour 2004: 10).

Bryson and Crosby (1992: 92) define Forums as: "A practice of linking speaker and audiences wherein meaning is created and communicated through discussion, debate, or deliberation." For instance, Forums can be "newspapers", "television", "professional journals", "discussion groups" or "public hearings." Based on this definition, we argue that during institutional change Forums are more prone to influence what Scott has defined as the "cultural-cognitive pillar", namely "a cultural cognitive conception of institutions stresses the central role played by the socially mediated construction of a common framework of meaning" (Scott 2001: 58). In general terms, public opinion is influenced by the dialog in Forums, more so than that in Arenas.

Whereas Forums include a broad range of actors involved in producing all forms of discourse, Arenas are the sites of formal policy development and see the involvement of a much narrower set of actors. Arenas are defined as the "participation by actors in a delimited domain of activity as part of the process of policy making". Their effect is "the maintenance or change of political and economic relations especially through distribution and redistribution of access to the exercise of power". Examples of Arenas are "corporate executive committees", "city councils" and "legis-latures"(Bryson/ Crosby 1992: 103). Therefore access to an Arena defines the ability of actors to exercise power over policy-making. The concept of Arenas is consistent with Scott's regulative pillar since: "Scholars more specifically associated with the regulatory pillar are distinguished by the prominence they give to explicit regulatory processes: rule-setting, monitoring, and sanctioning activities" (Scott 2001: 52).

As we shall see, the ambiguity of the ISO platform used to develop the 26000 standard lies in its shifting position from a Forum at certain times to an Arena at other times. While some stakeholders participate with the intention of entering a Forum, others do so intending to enter an Arena. ISO has succeeded thus far in providing both groups with what they desire. 


\section{ISO Positioning in the International Field of OSR: Maintaining a Fundamental Ambiguity}

\subsection{ISO as a Forum}

According to institutional theory, stakeholders defending an interest already have a central position in the field. They are in a position of "hegemony" with resources and a central position in the institutional arrangement (Levy/Scully 2007). This means that they have control over existing Arenas, therefore control over political agendas and hence would prefer not to see any new Arenas emerge. This idea of keeping control over the political agenda has been well-researched in political science (Lukes 2004). None-the-less, taking part in a Forum is a way for the powerful to keep an eye on what Berger and Luckmann have called the "social provinces of meaning", which are marginal institutions that could eventually become competitors to dominant institutions. The powerful may seek to annihilate - that is, in Berger and Luckmann's terms, to delegitimize - these marginal institutions if necessary (Berger/Luckmann 1967). Hence, these stakeholders can accept the emergence of a new Forum rather than an Arena which is actually vested with power.

The potential of platforms to become Forums has already been recognized in the literature. Brown and David (1991) have theorized platforms as "bridging organizations" that constitute a "conduit of ideas" and practices that mediate across various social provinces. Meanwhile, according to Trist (1983), "referent organizations" are at the nexus of social movements and can provide members with an "appreciation" of future trends (Trist 1983: 275).

For the ILO, as mentioned by one of our interviewees, a key motive for taking part in the process was "the importance to learn from ISO and other actors". As a matter of fact, several authors have reported ISO's "low profile" image as an incentive for major players to step in (Tamm Hallström 2004: 25). Early in the process, ISO appeared as a Forum by officially eschewing its original goal to make the standard certifiable. This restriction limited the standard's impact in "monitoring, and sanctioning activities", and distanced ISO 26000 from international regulations such as those provided by the World Trade Organization (WTO). ISO also provided some effective guarantees to international organizations that they would be able to influence the process. This was known within ISO as a Memory of Understanding (MOU): the power to participate and comment throughout the entire process. For instance, the ILO was provided with such a privilege along with the "veto power over labor related sections" (Castka/Balzarova 2007: 85). From this we derive proposition 1:

Proposition 1: for opponents to change, ISO has managed to appear as a credible Forum - and not as an Arena - since the beginning of the process.

\subsection{ISO as an Arena}

However, stakeholders defending perspectives experienced two important barriers that hampered their participation in the ISO 26000 development process. First, the costs associated with their participation, which have been discussed by several authors in the field (Tamm Hallström 2005). Stakeholders defending a perspective need to justify the costs to their funders. Even though ISO has set up specific funds to facili- 
tate participation, most stakeholders are participating at their own cost which has undermined the democratic aspect of the process (Igalens 2009). Second, it is not clear whether ISO is a private organization defending private interests or a public organization working for the common good. Some stakeholders have expressed their concerns that the ISO 26000 standard will reflect the interests of the consulting industry because of the business it will eventually generate for them (Castka/Balzarova 2008). As mentioned during one of the preliminary interviews, stakeholders representing a perspective were afraid of being used as legitimating puppets without having the chance to influence the outcome of the process. Therefore, such stakeholders have little desire to take part in yet another Forum, but instead they would prefer to step into an Arena. They believe it is only if the platform is vested with policy-making power that they can influence organizations' day-to-day operations. No doubt ISO's past record with the certifiable standards ISO 9000 and 140000 was taken into consideration. Those standards have yielded a total of more than 1,000,000 certifications around the world (ISO 2008).

Platforms have been recognized as having the potential to become Arenas in the literature. They have been discussed as having the capacity to establish "common ground rules" with the capacity to serve as "infrastructure support" (Castka/Balzarova 2005: 275). The literature also reports occasions where platforms have "mobilized and channeled the resources and energy" (Brown 1991).

More purposefully, ISO has also placed a strong emphasis on the procedural justice of this process. A strong argument advanced by ISO during the launch of the process in 2004 was that, given that 75 percent of its membership was made up of developing countries, these countries could expect to have a greater impact on the definition of OSR standards here than in any other place (Castka/Balzarova 2008). A shared presidency was established between national representatives from Sweden and Brazil, a developed and developing country respectively. A similar structure was replicated throughout all subcommittees. These subcommittees were presided over by a "twin arrangement", that is they were co-chaired by an expert from a developed country and an expert from a developing country. ISO did its best to appear as a credible and fair Arena for those actors. Hence proposition 2:

Proposition 2: to advocates for change, ISO has managed to appear as a credible Arena and not simply a Forum.

Table 1 below recaps the definitions and effective outcomes from the collective structures favoring institutional work described above. 


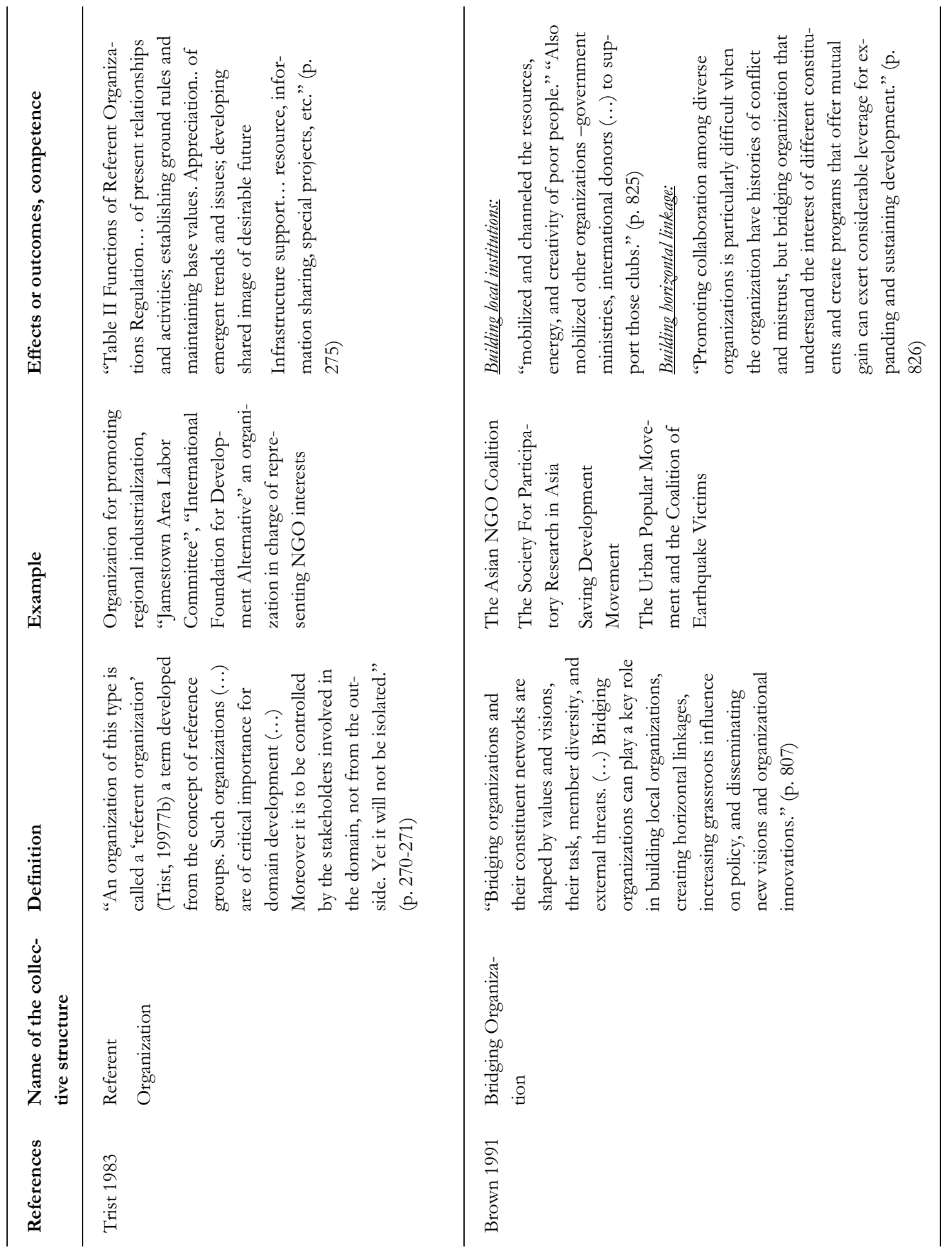

zfwu 12/1 (2011), 32-47 


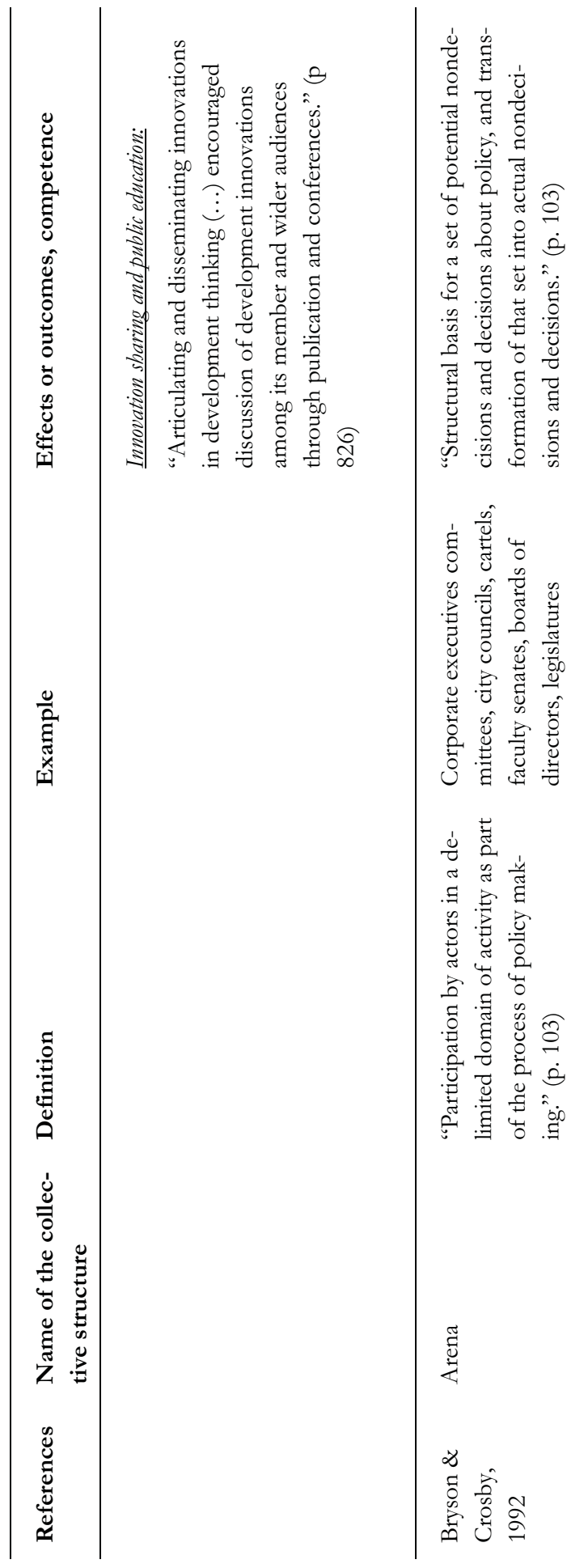

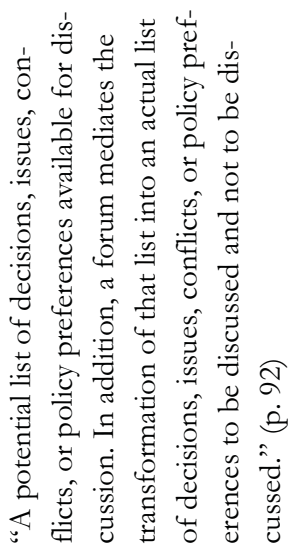

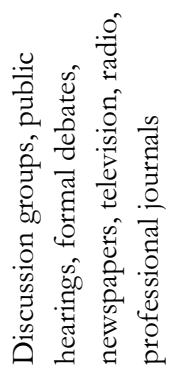

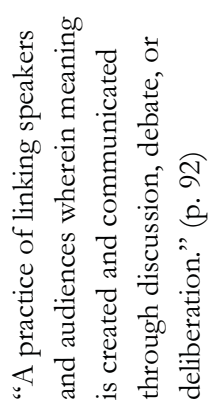

쿵

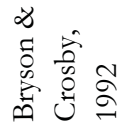




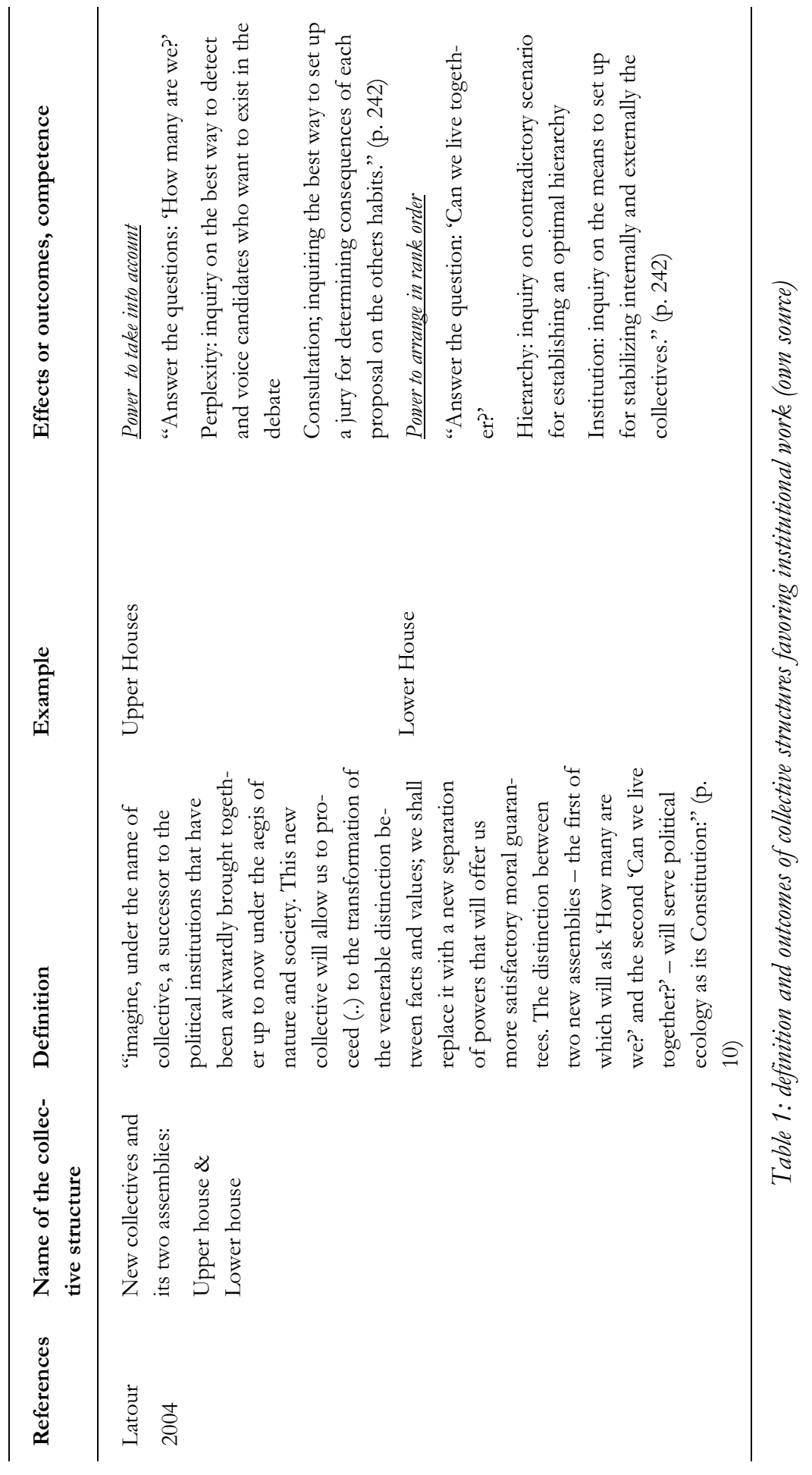

zfwu 12/1 (2011), 32-47 


\subsection{ISO as a Political Place}

In order to better acknowledge the ambiguity ISO was able to set up, it is necessary to understand that as a political place the platform appeared both as a credible Forum and Arena, a dual nature on which ISO played skillfully.

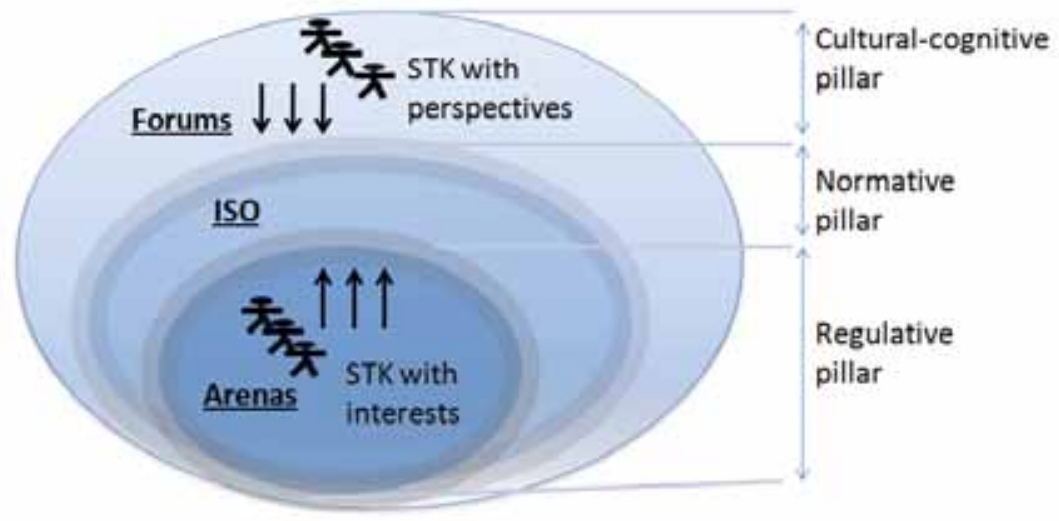

Figure 1: distribution of the institutional levers among the different political places and institutional actors (own source)

Though sometimes ISO may appear to be more of a Forum, it is in fact positioned at the border of the Arenas as described in figure 1. As we have explained, stakeholders defending interests tend to push in this direction. It then appears as a place to express debate and opinion. Indeed, in this case ISO is very close to what Latour (2004) has described as the "upper house" in Politics of Nature. It has "the power to take into account", that is to say to list the most important statement in the field of OSR, and eventually, in the case of ISO, to register them in a written document: ISO 26000. When first asked to reflect on the possibility for ISO to develop a standard on OSR in 2000, COPOLCO - the group usually defending consumer interests within ISO - set up an internet-based Forum with completely free, open and public participation. At that time, it is obvious that ISO 26000 was more of a Forum.

Sometimes ISO is more of an Arena. However, this Arena is always close to being a Forum. As described in figure 1, not only stakeholders representing a perspective are pushing in this direction, but arguably also ISO itself since it is looking for some gains in terms of political power (Brunsson/Jacobsson 2005; Murphy/Yates 2009). ISO is then very similar to Latour's concept of "lower house"(Latour 2004). It has the power to arrange in rank order the stakeholders' different propositions on OSR and to translate them into a meaning common to every stakeholder involved in the process. For example, the current version of the text has referenced and ranked in terms of relevance many of the other initiatives for Corporate social responsibility (ISO/DIS 26000, Table 1.A). 
Returning to theory, let us sum up what hypotheses can be formulated from the analysis of ISO 26000 as a Platform. Recall that ISO plays on its dual nature, sometimes being more of a Forum, sometimes more of an Arena. This ambiguity allows it to satisfy both advocates for and opponents to change. In terms of institutional change, ISO does not directly affect the "ineffable" cognitive pillar of institutions constructed in Forums, neither does it have the power of changing directly the regulative pillar as an Arena. Hence it intervenes more on the normative pillar "which define goals or objectives [...] but also designate appropriate ways to pursue them" (Scott 2001: 55). In this manner, it managed to have opponents and advocates of institutional change in the OSR regulation field interacting together. Hence proposition 3:

Proposition 3: platforms should play on their dual nature, sometimes being more of an Arena, sometimes more of a Forum to attract opponents and advocates of institutional change to work together.

\section{Conclusion}

In this paper, we have further developed the role of ambiguity in the development of standards and norms for OSR and the way it is used by a platform favoring institutional change. In the past, traditional international Arenas such as ILO and the UN have tried with mixed success to regulate OSR; meanwhile international Forums like the International Forum on Globalization or the World Social Forum and others usually lacked the power to regulate directly. Today, with ISO 26000, ISO unveils another type of political place. Neither Forum nor Arena, ISO's platform is a hybrid political place. Its capacity to emulate both Forums and Arenas enabled ISO to bridge the divide between advocates and opponents of change and eventually successfully develop standards of OSR.

\section{References}

Ahrne, G./ Brunsson, N. (2008): Meta-organizations. Cheltenham: Edward Elgar.

Beck, U. (2008): Reframing Power in the Globalized World, in: Organization Studies, Vol. 29/No. 5, 793-804.

Berger, P. L./Luckmann, T. (1967): The social construction of reality: a treatise in the sociology of knowledge, London: Penguin.

Brown, L. D. (1991): Bridging Organizations and Sustainable Development, in: Human Relations, Vol. 44/No. 8, 807-831.

Brunsson, N./ Jacobsson, B. (2005): A world of standards, Oxford: Oxford University Press.

Bryson, J. M./ Crosby, B. C. (1992): Leadership for the common good: tackling public problems in a shared-power world, San Francisco, Calif.: Jossey-Bass Publishers.

Castka, P./ Balzarova, M. A. (2005): ISO management system standards and social responsibility connection: (not quite) joined-up opinions of ISO's stakeholders, in: Total Quality Management and Excellence, Vol. 33/No. 3, 119-124.

Castka, P./ Balzarova, M. A. (2007): A critical look on quality through CSR lenses, in: The International Journal of Quality \& Reliability Management, Vol. 24/No. 7, 738-752. 
Castka, P./ Balzarova, M. A. (2008): Social responsibility standardization: Guidance or reinforcement through certification?, in: Human Systems Management, Vol. 27/No. 3, 231-242.

Czarniawska, B. (2009): Emerging Institutions: Pyramids or Anthills?, in: Organization Studies, Vol. 30/No. 4, 423-441.

DiMaggio, P. (1991): Constructing an Organizational Field as Professional, in Powell \& DiMaggio: The New institutionalism in organizational analysis, Chicago: University of Chicago Press, 267-292.

Dorado, S. (2005): Institutional Entrepreneurship, Partaking, and Convening, in: Organization Studies, Vol. 26/No. 3, 385-414.

Douglas, M. (1986): How institutions think, Syracuse, N.Y.: Syracuse University Press.

Egyedi, T. M./ Toffaletti, S. (2008): Standardising Social Responsibility: Analysing ISO representation issues from an SME perspective, paper presented at the 13th EURAS Workshop on Standardisation, Aachen, Germany.

Garud, R./ Hardy, C./ Maguire, S. (2007): Institutional Entrepreneurship as Embedded Agency: An Introduction to the Special Issue, in: Organization Studies, Vol. 28/No. 7, 957-969.

Glaser, B. G. (1992): Emergence vs forcing: basics of grounded theory analysis, Mill Valley, CA: Sociology Press.

Greenwood, R./ Suddaby, R./ Hinings, C. R. (2002): Theorizing change: The role of professional associations in the transformation of institutional fields, in: Academy of Management Journal, Vol. 45/No. 1, 58-80.

Igalens, J. (2009): Norme de responsabilité et responsabilité des normes: le cas d'ISO 26000. (French), in: Revue Management et Avenir, No. 23, 91-104.

ISO (2008): The ISO Survey of Certification, Geneva: ISO.

ISO Advisory Group on Social Responsibility (2004): Working Report on Social Responsibility, Geneva: ISO.

Langley, A. (1999): Strategies for theorizing from process data, in: Academy of Management. The Academy of Management Review, Vol. 24/No. 4, 691-710.

Latour, B. (2004): Politics of nature: how to bring the sciences into democracy, Cambridge, Mass.: Harvard University Press.

Levy, D./ Scully, M. (2007): The Institutional Entrepreneur as Modern Prince: The Strategic Face of Power in Contested Fields, in: Organization Studies, Vol. 28/No. 7, 971-991.

Ligteringer, E./ Zadek, S. (2005): The Future of Corporate Responsibility Codes, Standards and Frameworks, Executive Briefing by Global Reporting Initiative and AccountAbility, in: http://www.greenbiz.com/sites/default/files/document/CustomO16C45F63376. pdf, website accessed in October 2010.

Lukes, S. (2004): Power: a radical view, Houndmills et al.: Palgrave Macmillan.

Maguire, S./ Hardy, C. (2006): The Emergence of New Global Institutions: A Discursive Perspective, in: Organization Studies, Vol. 27/No. 1, 7-29.

Miles, M. B./ Huberman, A. M. (1994): Qualitative data analysis: an expanded sourcebook, Thousand Oaks: Sage Publications.

Murphy, C./ Yates, J. (2009): The International Organization for Standardization (ISO): global governance through voluntary consensus, London/New York: Routledge.

Patton, M. Q. (2002): Qualitative research \& evaluation methods, Thousand Oaks: Sage Publications. 
Pettigrew, A. M. (1990): Longitudinal Field Research on Change: Theory and Practice, in: Organization Science, Vol. 1/No. 3, 267-292.

Runvet, C. (2009): Que représentent les stakeholders: des perspectives ou des intérêts? Le cas d'ISO 26000, future norme internationale sur la responsabilité sociétale des organisations, paper presented at the $4^{\text {th }}$ RIODD Conference "La RSE: une nouvelle régulation du capitalisme?", Lille, France.

Scott, W. R. (2001): Institutions and organizations, Thousand Oaks, Calif.: Sage Publications.

Seo, M.-G./ Creed, W. E. D. (2002): Institutional Contradictions, Praxis, and Institutional Change: a Dialectical Perspective, in: Academy of Management Review, Vol. 27/No. 2, 222-247.

Tamm Hallström, K. (2004): ISO Enters the field of Social Responsibility (SR) - growing importance of non-state actors in global governance, paper presented at the WZB/CARR conference "Global Governance and the Role of Non-State Actors", London.

Tamm Hallström, K. (2005): International Standardization Backstage - legitimacy and competition in the social responsibility (SR) field, paper presented at the 21st EGOS Colloquium "Unlocking organizations", Berlin, Germany.

Tolbert, P. S./ Zucker, L. G. (1996): The Institutionalization of institutional theory, in Clegg, Hardy \& Nord, Handbook of organization studies, London: Sage Publications, 175-190.

Trist, É. (1983): Referent Organizations and the Development of Inter-Organizational Domains, in: Human Relations, Vol. 36/No. 1, 269-284.

Turcotte, M.-F./ Pasquero, J. (2001): The paradox of multistakeholder collaborative roundtables, in: The Journal of Applied Behavioral Science, Vol. 37/No. 4, 447-464.

Waddock, S. (2008): Building a New Institutional Infrastructure for Corporate Responsibility, in: Academy of Management Perspectives, Vol. 22/No. 3, 87-108.

Yin, R. K. (2009): Case study research: design and methods, Los Angeles, Calif.: Sage Publications. 